2. ECN Category
(mark one)
Supplemental
Direct Revision
Change ECN
Temporary
Standby
Supersedure
Cancel/Void

12e. Modification Work

[ ] Yes (fill out Blk. 12b)

[x] Ho (HA Blks. 12b, 12c, 12d)

13a. Description of Change

3. Originator's Name, Organization, MSIN, and Telephone No.

J. T. Quigley, GS/OF, s6-30, 373-7393

6. Project Title/No./Work Order No.

TF Solid Waste Characterization Guide \& SAP

9. Document Hubers Changed by this ECM (includes sheet no. and rev.) WHC-SD-WM-PLN-119, REV. 0

12b. Work Package 12c. Modification Work Complete No.

$\mathrm{N} / \mathrm{A}$ $\mathrm{N} / \mathrm{A}$ Hes

Design Authority/log. Engineer Signature \& Date

13b. Design Baseline Document?

[] Yes [x] No

This document has been updated to include improvements and additions to the characterization of tank farms solid waste.

The document title has changed to Tank Farms solid waste Characterization Guide With Sampling And Analysis Planned Attachment.
5. Date

$03 / 31 / 97$

8. Approval Designator N/A

11. Related PO No.

N/A

12d. Restored to Original Condi$t i$ on (Temp. or Standby ECN only) N/A
Design Authority/Cog. Engineer signature \& Date

14a. Justification (mark one)

Criteria Change [ ] Design Improvement

As-Found [] Facilitate const []

Envirormental

[x]

Facility Deactivation

14b. Justification Details

This is a RFSH milestone requirement.

see diatribution cover gheet.
15. Distribution (include name, MSIN, and no. of copies)

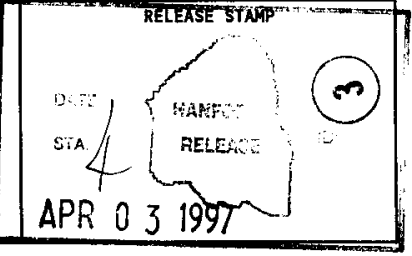

A-7900-013-2 (05/96) GEF095 


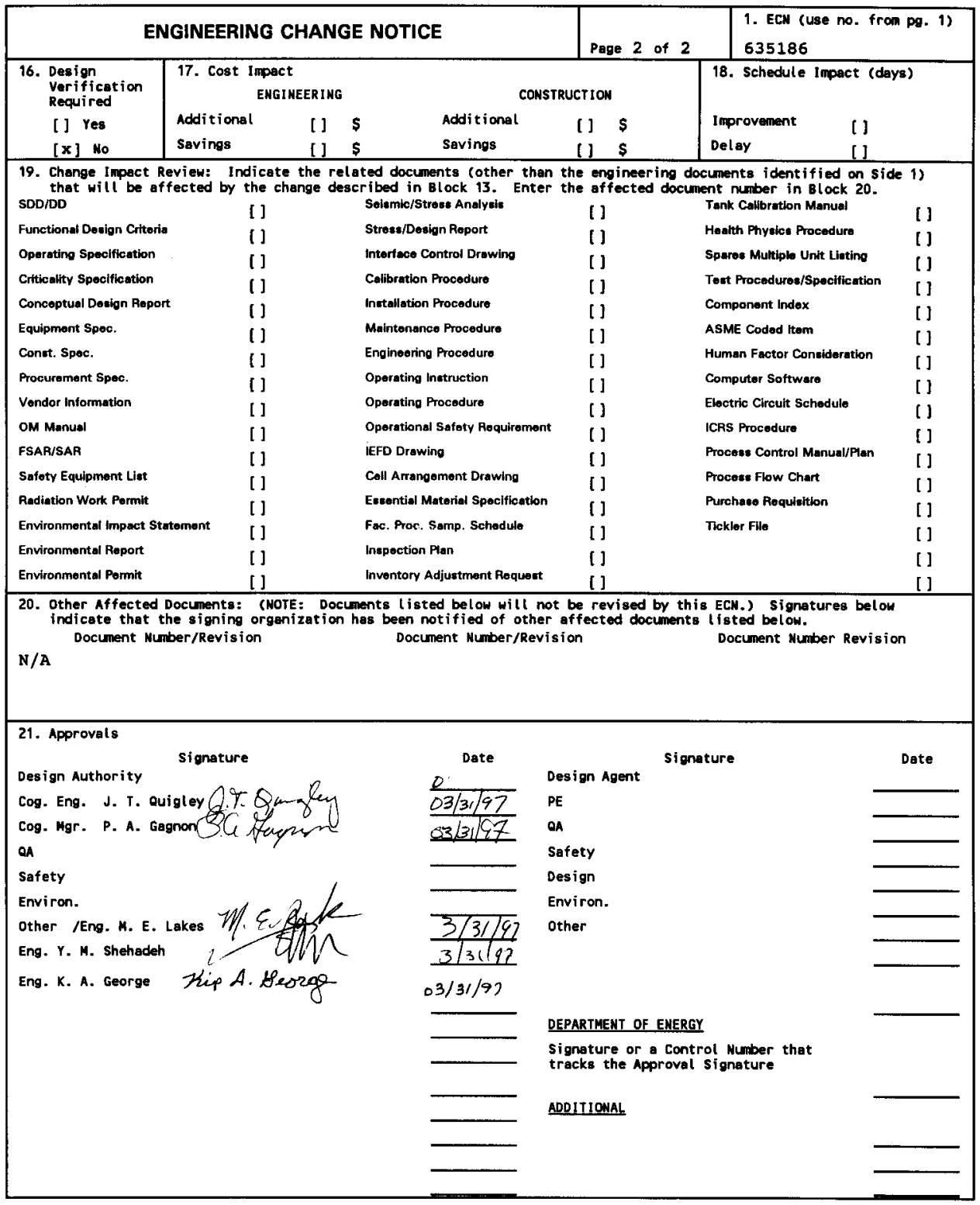




\title{
Tank Farms Solid Waste Characterization Guide With Sampling And Analysis Plan Attachment
}

\author{
J. T. Quigley \\ RUST Federal services of Hanford, Inc., Richland, WA 99352 \\ U.S. Department of Energy Contract DE-AC06-96RL13200

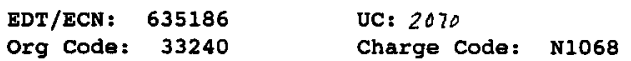 \\ Key Words: Hazardoug Chemical Characterization, solid waste, Tank \\ Farms, Sampling and Analysis.
}

Abstract: This document describes methods used, including sampling and analysis, to characterize hazardous chemical constituente in Tank Farms containerized solid waste.

TRADEMARK DISCLAIMER. Reference herein to ony specific commercial product, process, or service by trade name, trademark, manufacturer, or otherwise, does not necessarily constitute or imply its endorsement, recommendation, or favoring by the United states Goverment or any agency thereof or its contractors or subcontractors.

Printed in the United States of America. To obtain copies of this document, contact: Document Control Services, P.O. Box 950, Mailstop H6-08, Richland WA 99352, Phone (509) 372-2420;

Fax (509) 376-4989.
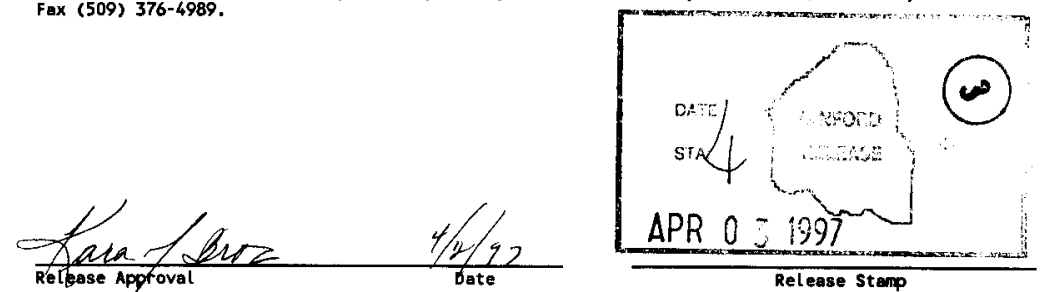

\section{Approved for Public Release}




\section{RECORD OF REVISION}

(1) Document Number

HNF-SD-WM-PLN-

Page 1

119, REV. 1

(2) Title

Tank Farms Solid Waste Characterization Guide With Sampling and Analysis Plan Attachment

CHANGE CONTROL RECORD

(3) Revision (4) Description of Change - Replace, Add, and Delete Pages 0

1 RS

(7) Change document title and update characterization information. (ECN635186
Authorized for Release

(5) Cog. Engr. (6) Cog. Mgr. Date

J. T. RT.

ouigley O) 3 Q Heomenskik7

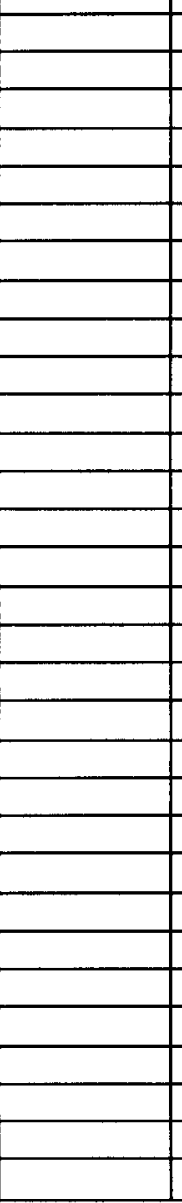


HNF-8D-WM-PLN-119, REV. 1

TANK FARMS SOLID WASTE CHARACTERIZATION GUIDE

WTTH

SAMPLING AND ANALYSIS PLAN ATTACHMENT

Prepared by Jean T. Quigley

March, 1997

For Rust Federal Services Hanford (RFSH) 
HNF-SD-WM-PLN-119，REV, 1

TABLE OF CONTENTS

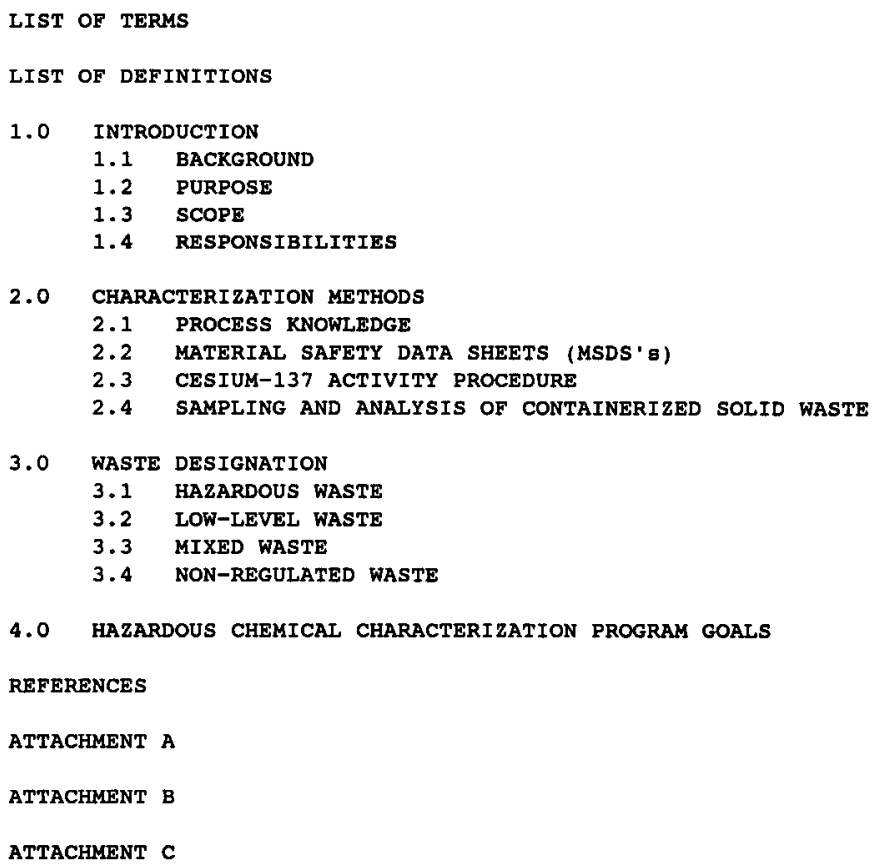


BMP-SD-WL-PIN-119, REV , 1

LIST OF TERMS

\begin{tabular}{|c|c|}
\hline \multirow{3}{*}{$\begin{array}{l}\text { ALARA } \\
\text { AS } \\
\text { ASTM }\end{array}$} & \multirow{2}{*}{$\begin{array}{l}\text { as low as reamonably achievable } \\
\text { Analytical services }\end{array}$} \\
\hline & \\
\hline & American Society for Testing and Materials \\
\hline & Code of Federal Regulations \\
\hline $\mathrm{Cs}-137$ & Cesium-137 \\
\hline CWDR & Chemical Waste Dezignation Requeat \\
\hline DOE & U.S. Department of Energy \\
\hline EPA & U.S. Environmental Protection Agency \\
\hline FDH & Fluor Daniel Hanford, Inc. \\
\hline GS/OF & Generator Services/Operating Facilities \\
\hline GS/O & Generator Services/Operations \\
\hline HAZCAT & Hazardous Categorization \\
\hline HEPA & High-efficiency Particulate Air (Filter) \\
\hline HPT & Health Physics Technicians \\
\hline HSQMP & Hanford Sampling Quality Management Plan \\
\hline HWDAR & Hazardous Waste Designation Analysis Report \\
\hline LDR & Land Diaposal Restrictions \\
\hline LLW & Low-Level Waste \\
\hline LMHC & Lockheed Martin Hanford Corporation \\
\hline MSDS & Material safety Data sheet \\
\hline MW & Mixed Waste \\
\hline $\mathrm{mg} / 1$ & milligrams per liter \\
\hline NHC & Numatec Hanford Corporation \\
\hline PCBa & Polychlorinated biphenyla \\
\hline PIN & Package Identification Number \\
\hline ppm & parts per million \\
\hline $\mathbf{Q A}$ & quality aseurance \\
\hline $\mathbf{Q C}$ & quality control \\
\hline RCRA & Resource Conservation and Recovery Act \\
\hline RFSH & Rust Federal Services of Hanford, Inc. \\
\hline RFSNW & Rugt Federal Services Northweat \\
\hline SAP & Sampling and Analysis Plan \\
\hline SAS & special Analytical support \\
\hline SDLA & Sample Data and Laboratory Administration \\
\hline SML & Sampling and Mobile Laboratories \\
\hline SVOA & semi-volatile organic analysis \\
\hline $\mathbf{T C}$ & Toxicity characteristic \\
\hline TCLP & Toxicity Characteristic Leaching Procedure \\
\hline TCRB & Tank Characterization Reports \\
\hline TCRC & Tank Characterization Resource Center \\
\hline $\mathrm{TF}$ & Tank Farms \\
\hline TS & Technical Services \\
\hline TSCA & Toxic Subatance control Act \\
\hline TWRS & Tank Waste Remediation Syatems \\
\hline VOA & volatile organic analysis \\
\hline voc & volatile organic compound \\
\hline WDOE & Washington state Department of Ecology \\
\hline WSCF & Waste Sampling and Characterization Facility \\
\hline
\end{tabular}




\section{Carcinogen}

Any substance that can cause or contribute to the production of cancer.

Characteristic

Any one of the four categories used in defining hazardous waste: ignitability, corrosivity, reactivity, and toxicity.

Constituent or Dangerous Waste Constituent

A chemically distinct component of a dangerous waste stream or mixture (wHC 173-303-040).

\section{Corrosive Material}

A liquid or solid that causen viaible destruction or irreversible alterations in human skin tissue at the site of contact, or a liquid that has a severe corrosion rate on steel or aluminum. (49 CFR 171.8)

Curie or $\mathrm{Ci}$

A quantitative measure of radioactivity equal to $3.7 \times 10^{10}$ disintegrations per second.

\section{Dangeroug Waste}

Waste that is listed as a dangerous waste, exhibits the characteristic(s) of hazardous waste (i.e., ignitable, corrosive, reactive, and/or toxic), or meets the criteria for dangerous waste (i.e., toxicity, or persistence). The lists, characteristics, and criteria are specified in พAC $173-303$.

\section{Detection Limit}

Lowest amount that can be distinguished from the normal random "noige" of an analytical instrument or method.

Equivalent Method

Any testing or analytical method other than the U.S. EPA's criteria $(40 \mathrm{CFR}$ $53.11,53.16,60.2,61.02,260.10)$.

\section{Field Sampling Plan}

Providea guidance for all fieldwork by defining in detail the sampling and data-gathering methods to be used on a project.

\section{Halogenated Hydrocarbong}

Family of compounds consisting of hydrocarbons bonded to one or more halogen atoms (fluorine, chlorine, bromine, or iodine). 
Hazardous Waste

Those solid wastes designated by 40 CFR Part 261, and regulated as hazardous and/or mixed waste by the USEPA. (WAC 173-303-040), (40 CFR 260.10), (10 CFR 61.2), (DOE Order 5820.2A Attachment 2), (49 CFR 171.8)

\section{Heavy Metalo}

A set of metals which are commonly measured because of their high toxicity. They can damage living things at low concentration and tend to accumulate in the food chain. The geries includes: argenic (As), barium (Ba), cadmium (Cd), chromium ( $\mathrm{Cr}$ ), lead ( $\mathrm{Pb}$ ), mercury ( $\mathrm{Hg}$ ), selenium (Se), and silver (Ag).

\section{Holding Time}

The amount of time allowed to elapse from sample collection until laboratory analysis and/or extraction as specified by the contract, statement of work, method, or regulatory requirement.

Ignitability

Identifies a waste that may cause a fire during routine disposal and storage conditions. (WAC 173-303-090 [5]), (WAC 173-303-040)

\section{Listed Waste}

Wastes which are designated under WAC 173-303-080 through -082 .

\section{Low-Level Waste}

Waste that contains radioactivity and is not classified as high-level waste, transuranic (TRU) waste, or spent nuclear fuel or 11E(2) byproduct material as defined by DOE Order 5820.2A.

Material Safety Data Sheet (MSDS)

A compilation of information required under the osHA communication standard on the identity of hazardous chemicals, health, and physical hazards, exposure limits, and precautions.

\section{Mixed Waste}

Waste containing both radioactive and hazardous components as defined by the Atomic Energy Act (ATEA) and the Resource Conservation and Recovery Act (RCRA), respectively. (10 CFR 20.1003)

\section{$\underline{\mathrm{PCBg}}$}

A group of toxic, peraistent chemicals (polychlorinated biphenyls) used in transformers and capacitators for insulating purposes, and in gas pipeline systems as a lubricant.

\section{Pergistence}

Refers to the length of time a compound, once introduced into the environment, atays there. A compound may persist for less than a second or indefinitely.

$\underline{\mathrm{pH}}$

A measure of the acidity or alkalinity of a liquid or solid material. 
MNF-SD-MA-PIN-119, REV . 1

Procesg Knowledge

Documented evidence of past or current industrial (including chemical)

practices.

Quality Assurance (OA)

An integrated system or program of activities involving planning, quality control, quality assessment, reporting and quality improvement to ensure that a product or service meets the defined atandards of quality with a stated level of confidence.

Quality Control (OC)

The overall system of routine technical activities whose purpose is to measure and control the quality of a product or service so that it meets the needs of its users.

\section{Radioactive Material}

Any material having a specific activity greater than 0.002 microcurles per gram (uCi/g). (49 CFR 173.403)

Radioactive Wagte

Solid, liquid, or gaseous materials, of no commercial value that emits ionizing radiation. Discarded items such as clothing, containers, equipment, rubble, residues, or soils that contain radionuclides.

Reactivity

Identifies wastes that presents a hazard because they are unstable or extremely reactive. (WAC 173-303-090 [7]), (WAC 173-303-040)

\section{Sample}

(1) Material or a set of samples drawn from a larger set or population that is taken to represent the larger. A single sample can comprise a sample; however, statistical constraints generally require that a sample be comprised of no less than three samples. (2) A portion or subset of a population selected to be representative of the population.

\section{Sampling}

The process of selecting a set of samples from a given population in accord with a preselected scheme for determining which samples to take and when to take them. At some level the selection of samples should be fully randomized.

\section{Split Sample}

Samples taken from a single homogenous medium, placed in separate containers and sent to separate laboratories for analysis by the same method/protocol.

Toxicity

The degree of danger posed by a substance to animal or plant life. A solid waste has the characteristic of toxicity if the TCLP test shows that the extract from a representative sample contains specified contaminants at a concentration equal to or greater than that called for by RCRA Regulations. 
Toxicity Characteristica Leaching Procedure (TCLP)

The procedure by which a waste is determined to exhibit the toxicity

characteristic. If, by using tegt methods specified in Appendix II of 40 CFR 261, or equivalent methods approved by the EPA Administrator, the extract from a representative sample of a waste contains contaminants listed in Table $I$ of $40 \mathrm{CFR} 261.24$ at concentrations equal to or greater than the values in that table, the waste exhibitg the toxicity characteriatic.

\section{Trip Blank}

An analyte ample container filled with pre-certified silica sand which is transported to the sampling site, and returned to the laboratory with the samples. Trip blanks are filled in the laboratory and are not to be opened in the field.

Volatile Organic Compound (Voc)

Any organic compound which participates in atmospheric photochemical reactions, except for those designated by the EPA Administrator as having negligible photochemical reactivity. Any component containing carbon and hydrogen or containing carbon and hydrogen in combination with any other element which has a vapor pressure of 1.5 pounds per gquare inch absolute $(77.6 \mathrm{~mm}$. Hg) or greater under actual storage conditions (40 CFR 60.391, $60.461)$.

\section{Waste Container}

The waste, waste package, and any absorbent that are intended for disposal as a unit.

\section{Waste Stream}

A waste stream is any consigtent set of waste material from a given process or set of closely related processeg that does not change in its physical, radionuclide or chemical designation, or in its means of packaging. Waste streams are established to meet the requirements in the Waste Specification System document, WHC-EP-0846. 


\subsection{INTRODUCTION}

\subsection{BACKGROUND}

Lockheed Martin Hanford corporation (LMHC) manages the activities of the 200 East and Weat tank farms. Rust Federal services Hanford (RFSH), Generator Services/Operating Facilities (GS/OF) manages, for LMHC, all containerized solid waste generated from these activities. Activities that generate waste include, but are not limited to, routine maintenance, clean-up, upgrades, spills, excavations, and removal or repair of equipment.

The containerized solid waste is transported from the point of generation to the $209 \mathrm{E}$ facility. GS/OF receives waste which if classified as either Hazardous/Dangeroug, Low-Level, Mixed, or Non-Regulated waste. The waste is characterized for proper designation and then prepared for ehipment to a dieposal, storage, or recycle facility. Hazardous/Dangerous and Mixed waste must be characterized, designated and shipped within a 90-day holding period.

The regulatory drivers which require waste generators to characterize their waste streams are found in 40 CFR, Part 260 299, the Washington Administrative Code, Dangerous Waste Regulations, 173-303, and the Department of Energy Directives (DOE order 5820.2A). The "Hanford site solid Waste Acceptance Criteria", WHC-EP-0063-4 and "Waste Specification System", WHC-EP0846 also gives guidance to waste generators in characterizing waste streams. This document does not apply to high-level radioactive waste.

Hazardous chemical, physical, and radioactive characterization data and information is necessary to properly designate tank farm containerized solid waste for treatment, storage, disposal, and/or recycle. The following methods are presently used to acquire characterization information:

(1) process knowledge,

(2) Material Safety Data sheets (MSDS'g),

(3) Cesium-137 (Cs-137) activity ratiog, and

(4) sampling and analysis of solid waste. 
ENF-SD-WM-PLN-119, REV. 1

Solid waste is classified as either hazardous/dangerous, lowlevel, mixed, or non-regulated waste. Solid waste is also categorized into tank farm waste streams (i.e., tank-contacted debris including HEPA filters, soils, low-level debris).

\section{Hazardous/Dangerous Waste}

Hazardous waste is characterized by using process knowledge, material safety data sheet (MSDS) information, and when necessary, sampling and analysis data, particularly, for unknown wastes. (Washington state uses the term "Dangerous Wagte" to describe hazardous and extremely hazardous waste characterigticg and criteria).

\section{Low-Ievel Waste}

Low-level waste is characterized by using process knowledge, MSDS information, and sampling and analysis data.

\section{Mixed Waste}

Mixed waste is characterized by using process knowledge, the Cs-137 activity ratios, MSDS information, and sampling and analysis data.

\section{Non-requlated Waste}

Non-regulated waste is characterized by using process knowledge, MSDS information, and when necessary, aampling and analysis data.

\section{2 PURPOSE}

The purpose of this document is to discuss the current methods available and used to characterize hazardous chemicals in tank farm containerized solid waste.

\subsection{SCOPE}

This plan will discuss methods of waste characterization, with an emphasize on the sampling and analysis methods used to identify hazardoug chemicals in waste.

Radiological characterization of tank farms containerized solid waste is addressed in document WHC-SD-WM-PLN-115 ${ }^{(1)}$. 


\subsection{RESPONSIBILITIES}

Technical Services (TS)

- Reviews and approves Waste Portfolios submitted by Generating Services/Operating Facilitiea (Gs/OF).

- Issues Hazardous Waste Designation Analyeis Report (HWDAR) and reviews Chemical Waste Designation Request (CWDR).

Generating Services/Operating Facilities (Gs/OF)

- Defines, confirms, and verifies hazardous chemical characterization of containerized solid waste.

- Identifies colid waste containers in need of ampling and analysis. Requests waste sampling and analyses.

- Interface between GS/O and outside sampling (SML) organizations.

- Requesta waste analyses from special Analytical support, 222-s laboratory, or the Waste Sampling Characterization Facility (WSCF).

- Performs deaignation of waste based upon characterization data.

Generator Services/Operations (GS/O)

- Provide support and oversight of outside sampling organizations during sampling activities according to Tank Farm Plant Operating Procedure, TO-100-053.

Sampling and Mobile Laboratories (SML)

- Collects specified samples according to SAF.

- Ships samples to on-site and off-site laboratories.

- Maintains field logbook, prepares chain-of-custody records.

Special Analytical Support (Numatec Hanford Corp.)

- Provides trained scientists/technicians for field sampling and laboratory analysis of specified samples.

- Transports samples to laboratories.

- Documents sampling activities in a controlled logbook, prepares chain-of-custody records.

- Generates data report detailing analytical results, methods used, quality control samples. 
ENF-SD-KM-PLN-119, REV , 1

\subsection{CEARACTERI 2ATYON NETHODS}

\subsection{Process Knowledge}

\section{General Use}

Documented evidence of past or current industrial practices that use hazardous or non-hazardous chemicala, is used to characterize solid waste streams.

Process knowledge of chemical products used in operating or maintaining tank farm equipment is used in characterizing waste generated from clean-up activities or equipment maintenance and/or failures. Waste etreams could include paint wastes, shop cleanout waster, oil spill wastes, equipment chemical changeouta.

\section{Specific Use - Listed Wastes}

Mixed waste streams, in particular, tank-contacted debris and contaminated soil, specifically use process knowledge in defining listed waste issues.

Process knowledge is considered to be documented evidence of past or current industrial practices that use hazardous or "listed" chemicals, and indicates that these chemicals are found in current waste storage tanks. The contents of the waste tanks is presumed to be the primary source of any contamination found in the tank farms.

Past Hanford site chemical processing operations generated mixed waste. This mixed waste was traneferred from the chemical process plants to underground storage tanks on the Hanford site. The tanks are located in the 200 East and 200 West area tank farms.

There are 149 single-shell tanks with a collective deaign capacity of $91,880,000$ gallons. There are 28 double-shell tanks with a collective deeign capacity of $43,000,000$ gallons. The doubleshell tanks are used for the interim storage of mixed waste. These tanks are considered storage units.

In addition to the above tanks, there are numerous smaller capacity single- and double-shell tanks located within the farms, including a variety of waste storage and transfer tanks.

Tank waste hazardous chemical constituents have been determined by reporting 0.01 percent by weight of the net weight of the waste for each of the listed hazardous constituents. This method is consistent with the "derived-from rule", which requires solid waste that comes into contact with a listed waste (tank waste is a listed waste) be managed as a hazardous waste. 
"Listed" chemicals used in the extraction processes require that waste codes be assigned to the present waste. Waste codes may be assigned solely on the source of the waste and need not consider waste characteristics or compositiond. These codes may be for specific sources, such as wood preservation or for nonspecific sources. Hanford tank waste have been assigned the following non-epecific, source codes (2): F001, F002, F003, F004, and F005. A further explanation of waste codes may be found in 40 CFR Part 261.

Tank-contacted waste and contaminated soil is assigned the above codes due to the "derived-from" and "mixture" rules (3) and managed as mixed waste. Through process knowledge, it is believed that all the above F-codes apply to tank contacted waste.

However, all of the codes may not apply to every individual tank. Accurate documentation is unavailable for every introduction and transfer of listed waste, (i.e., listed solvents). Due to these past practices, the sbove codes are currently applied to all tank contacted waste.

Process knowledge detailing concentrations of the "liated" chemicals in the tank waste is limited at the present time. Ag current tank waste core sampling data becomes available, new information concerning "listed" chemicals will be used where appropriate to characterize solid waste. It is conservatively assumed that each of these "F-listed" chemicals is present in tank-contacted debris in concentrations of no more than 0.018 of the weight of the waste. Current data acquired from sampling of tank contacted waste supports this assumption, thus far.

Current sampling data results indicate that the "Flisted" chemicals are present in tank farm contaminated soil waste in the following concentrations:

Constituent

F001 (1,1,1-Trichloroethane)

F002 (Methylene chloride)

F003 (Acetone)

F003 (Methyl isobutyl ketone)

F004 (Cresols)

F005 (Methyl ethyl ketone)
Agsumed Concentration in Waste

$<1.0 \mathrm{mg} / \mathrm{kg}$

$<1.0 \mathrm{mg} / \mathrm{kg}$

$<10 \mathrm{mg} / \mathrm{kg}$

$<1.0 \mathrm{mg} / \mathrm{kg}$

$<10 \mathrm{mg} / \mathrm{kg}$

$<1.0 \mathrm{mg} / \mathrm{kg}$ 
The Hanford site procegseg which introduced "listed" chemicals to the tanke are:

haste Code

F001

Procese:

$(4)(5)$

\section{Organic Listed Chenical Waste}

$1,1,1$ - Trichloroethane (TCE)

Process knowledge indicates that a B-Plant activity, prior to 1988, generated the eource of 1,1,1 - Trichloroethane (TCE). A opent solvent solution containing TCE was used for crane decontamination activities. The crane was eprayed with TCE, and the TCE residue fluid drained thru the B-Plant process drainage system (cell 21 or cell 16) and then on into the low-level waste collection system.

The low-level waste generated in B-Plant was processed thru the B23-3 concentrator. The condensed vapor from operating the concentrator was collected in two 13,000 gallon holding tanks which was then transferred to the double-shell tank farms.

Haste Code

F002

F003

\section{Process:}

\section{Organic Listed Chemical Waste}

Methylene Chloride

Acetone

T-Plant performs decontamination activities on equipment to reduce or remove smearable radiological contamination. Depending upon the type of equipment and the nature of the contamination, the following decontamination methods have been used in the past: steam cleaning, high-pressure water application, blasting with dry and wet abrasives, acid/base chemical baths, and occasional cleaning by hand using small amounts of solvents and detergents. Waste from these procesges goes to Tank 15-1.

Although not currently used at T-Plant, previous operations used acetone and methylene chloride as decontamination agents. Between 1986 and 1988, four commercial decontamination solutions containing greater than $10 \%$ methylene chloride were used at $T-$ Plant. About 35 gallong of methylene chloride were used per year at T-Plant. Small amounts of acetone and methylene chloride may still be present in the tank system, thus making T-Plant waste a "listed" waste. 
BNF-SD-WK-PLN-119，REV . 1

Haste Code

F003

5003

\section{Organic Listed Chemical Waste}

Acetone

Methyl isobutyl ketone or (Hexone)

Procers:

(4)(6)

In addition, to itg use at T-Plant, Acetone was used in laboratories to dry glaseware and consequently, could have been discharged to the tank farms. Acetone is a volatile organic and probably originates from the evaporation and condensation process in the 242-A Evaporator. The DST waste has been determined to be a listed (F003) source because of the presence of Acetone. Consequently, the 242-A procese condeneate is also an F003 waste because it is derived from DST waste.

Between 1951 and 1966, the Redox Plant used a distillation procesa to clean Hexone for reuse in the bolvent extraction process. Hexone was first washed with sodium carbonate to remove the radiation-produced degradation producte, then distilled to remove the water that had dissolved in it during washing. The water left behind was combined with the high-level waste stream for final steam stripping in the plant's waste concentrator. This atep recovered any hexone dissolved in the high-level waste stream or in the water sent over from the distillation process. After ateam stripping the concentrated high-level waste was sent to boiling waste SSTs in the 241-S and 241-SX Tank Farms. Steam atripping is a recommended recovery technique for Hexone (40 CFR Part 268).

Waste code

F004

Process:

(8)(9)

\section{Oraanic Iisted Chenical Waste}

Cresols and Cresylic Acid

T-Plant documents and nuclear process operators state that the product "CTD-99", also referred to as Chemetrip, was used and stored at T-Plant. Considering the configuration of the liquid waste handling system at T-Plant, it is probable to suspect this source entered the tank system. "CTD-99" contains up to $20 \%$ cresylic acid, according to MSDS *10727. "CTD-99" was used as a tank cleaning agent or aprayed directly onto equipment being decontaminated. 
HNF-8D-WM-PLN-119, REV. 1

Wante code

F005

Procens:

(4)(6)

\section{Organic Lieted Chenical Waste}

Methyl ethyl ketone or (2-Butanone)

Methyl ethyl ketone was used in the Redox analytical (222-s) laboratories and may have been discharged through the drains to the tank farms.

Specific Use - Toxic substance control Act (TSCA) Waste

The Backlog Waste Program generated 769 drums and five boxes of tank farm soils to waste storage. During this program, Tank farms had no process knowledge of any Polychlorinated biphenyls (PCBs) contamination or spills within the farms that would designate and regulate the backlog soils for PCBB.

In 1996, additional waste sampling and analysis of the stored backlog soils occurred resulting in the determination that PCBs do exist in some of these soils. The detection of PCBs in these soils was unexpected and the source of the PCB contamination can not be identified in the tank farms.

The Toxic Substance Control Act (TSCA) regulates the management and dieposal of Polychlorinated biphenyla (PCBs). At one time, PCBs were used as a heat transfer fluid in Hanford capacitors and traneformers. PCBa have also been identifled as a component in heavy equipment hydraulic fluid. Electric Utilities has not identified any historical spills or leaks from any transformers located within the tank farms.

Due to this recent backlog goil aampling data information, all newly generated tank farm soil waste should be field screened for PCB contamination. If the field screen result indicates the presence of PCB above 1 ppm and there is no known source of contamination, then the waste should be managed under TSCA as regulated waste.

\subsection{Material Safety Data Sheats (MSDs=)}

Process knowledge of chemical products used during operations may identify other hazardous chemicals in the waste streams. Information concerning the hazards or non-hazards of these chemical products may be gathered from the Material Safety Data sheet (MSDS) provided by the product manufacturer. 
HWF-SD-WM-PLN-119, REV , 1

Information found on a chemical product MSDS may include:

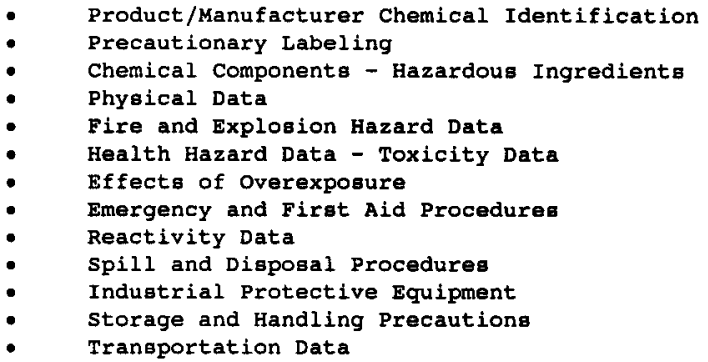

\subsection{Cesium-137 Activity Procedure (10)}

Tanks contain certain TCLP metals. Tank-contacted debris waste is not easily sampled for TCLP metals. Therefore, the concentration of the TCLP metals on tank-contacted debris is eatimated by relating metals to $\mathrm{Cs}-137$ concentrations. The Cesium(Cs)-137 activity procedure is used to provide a worst-case eatimate of toxicity characteristic (TC) metals for tank-contacted debris. This method uses the worst-case ratio of each TC metal to cs-137 activity from historical tank sampling data. If this method determines that a container may be designated for one of the TC metals, tank specific sampling data may be evaluated to determine more accurately whether a "D-" waste code should be added to the container. Typically, the cs-137 activity of a container must exceed $0.01 \mathrm{Ci}$ for there to be any possibility of adding waste codes for TC metals using this method.

Cs-137 activity determination in a laboratory or field setting is relatively easy and inexpensive. Cs-137 activity was selected to correlate the composition of individual waste packages to the composition of bulk tank waste.

First, constituent concentrations were compared to the Cs-137 activity for each waste tank using data available from historical tank characterization studies. Ratios of constituent concentration to $\mathrm{Ca}-137$ activity were then darived for each tank and then compared on a tank-to-tank basis. A worat-case ratio for each constituent was utilized to calculate a maximum expected concentration. In this manner a laboratory or field measurement of $\mathrm{Cs}-137$ activity may be used to calculate the amount of all significant tank waste constituents in each waste container. 
Worksheets were developed to simplify and organize the calculations required by the generator.

The following procedure is used to determine composition information on tank-contacted waste:

Step 1. Obtain the Ca-137 activity (in Ci) of the warte container by nondegtructive aseay of the container.

Step 2. Divide the CB-137 activity by the weight of the waste matrix (in grams). The waste matrix weight is defined as the weight of all waste materials inside the container, but DOES NOT include the weight of the waste container or any void apace filler materials. Enter the $\mathrm{Cs}-137$ concentration (in $\mathrm{ci} / \mathrm{g}$ ) in column 2 of Table 1-1, Attachment $A$.

Step 3. Multiply the Cs-137 concentration in column 2 by the ratios in column 3. Multiply that number by 1008 . Enter the results in column 5 .

Step 4. Determine whether the worgt-case ratio values from Column 5 are potentially above the WAC-173-303 limits.

Step 5. The TC constituent concentration is compared with the TC metal limits located in WAC-173-303-090(8), normalizing to account for dilution during the TCLP extraction.

If this method recults in a waste designation which is considered unnecessarily restrictive, laboratory data for each tank, tank farm, or waste container may be substituted for the values from Table 1-1. A catalog of data is maintained by the Tank Characterization Resource center (TCRC). The catalog is updated every six months. GS/OF is on the distribution list for this catalog, as well as for the Tank Characterization Reports (TCRs).

The ideal situation for characterization by scaling factors would be to have a complete, high-confidence database available for each tank to ensure that the calculated values of the hazardous and radioactive constituents remain conservative. Los Alamos National Laboratory (IATA) has been tasked with compiling an astimate of the chemical and radionuclide compositions of the 177 Hanford High Level Waste storage tanks. This inventory is entitled the Hanford Defined waste (HDW) model. The latest HDW Model, Rev. 4 was published in January, 1997, with the final revision due by late 1997. This inventory has been compiled from historical waste transaction records, tank waste addition histories, waste calculations, process knowledge, and tank waste-sampling characterization efforts. This final inventory, along with 
additional waste sampling and laboratory analysis, will assist in validating the characterization ratios used in this document. As more accurate data become available, the ratios will be updated and the degree of accuracy of waste characterization can be calculated and improved. Through process knowledge waste characterization should be documented and incorporated into a oampling and analysis program.

2.4 Sampling and Analysis of Containerized solid waste

Sampling and analyais of containerized solid waste provides information required to properly designate waste for storage, disposal and/or recycle. Sampling and analysis of waste verifies what is known to be true about the waste stream from process knowledge, in addition to providing new information concerning the hazardous or non-hazardous components of the waste. The generator is responsible for providing accurate waste designation in order to safely transport, store, dispose, and/or recycle the waste in compliance with state and federal regulations.

Sampling and analysis of containerized waste is and will continue to be the best means available for characterizing and designating solid waste. Representative sampling and the subsequent snalysis of suspected chemical contaminants of a current waste stream, helpa determine the true nature of the waste. The more accurate waste streams are characterized, the better generated waste is managed, thus allowing for a more efficient run operation and waste management cost savings.

Sampling and analysis of containerized solid waste is required when one of the following conditions exist:

(1) limited availability of process knowledge,

(2) verification needed of process knowledge or $\mathrm{Cs}-137$ ratio,

(3) suspect chemical contaminants associated with waste,

(4) Iimited availability of waste stream data,

(5) Iimited availability of specific tank or specific tank farm waste stream data,

(6) redesignation issue (1.e, change in waste stream),

(7) all containerized tank farm soil will be field acreened for Polychlorinated biphenyls (PCBs) content using the Sw-846 immunoassay method 4020. This method identifies the presence of PCBs to a level of $1 \mathrm{ppm}$. The Toxic 
HWF-SD-WM-PLN-119, REV, 1

Substance control Act (TSCA) regulates PCB contaminated media when the PCB source concentration is greater than $50 \mathrm{ppm}$. If the field screening indicates that the soil has PCB contamination at the $1 \mathrm{ppm}$ level or greater, and there is no known source, then the soil will be regulated under TSCA.

Container sampling selection is made due to any of the above conditions, in addition to appropriate dose rate, and budget constraints. Data acquired through sampling and analysis may result in no change in waste designation or a redesignation of the waste.

See Attachment B: "Tank Farms Containerized Solid Waste Sampling and Analysis Plan", for the steps used to acquire waste samples and analysis data.

\subsection{Waste Designation}

Upon acquiring sufficient waste characterization information, the following records are prepared for the formal waste designation:

\subsection{Hazardous Waste}

A Chemical Waste Designation Request (CWDR) is prepared and submitted to Technical Services (TS), accompanied by hazardous chemical characterization information and data. Waste designation is made and a Hazardous Waste Disposal Analysis Record (HWDAR) is issued to the generator. The waste may then be shipped for storage or disposal.

\subsection{Low-Level Waste}

A Waste Certification Summary is prepared for submittal to Ts when sufficient hazardous chemical, radiological, and physical characterization information is collected concerning a waste stream.

Upon approval, these summaries become the guidelines for waste stream designation. If the waste stream should change significantly, characterization must address the change and a new waste summary prepared for TS. The waste may then be shipped for storage or disposal. 
HNF-SD-WH-PLN-119, REV, 1

The following waste certification summariee have been prepared and submitted to TS:
(1) Miscellaneous Supercompacted
Low-Level Wagte Debris
(2) Noncompacted Low-Level Waste Debris
WSRd $* 100-00$
(3) Low-Level Absorbed Organic Waste
WSRd $* 106-00$
(4) Noncompacted Low-Level Laundry By-Product wsRd \$100-00d
(5) Supercompacted Low-Level Laundry By-Product
WSRd $* 100-02$ a
(6) Low-Level Tumbleweeds
WSRd $* 100-00 \mathrm{~b}$
(7) Low-Level HEPA Filters
WSRd $\$ 100-000$

\subsection{Mixed Waste}

A Waste Certification summary is prepared for submittal to Ts when sufficient hazardous chemical, radiological, and physical characterization information is collected concerning a waste stream.

Once approval is given, these summaries become the guidelines for waste stream designation. If the waste stream should change significantly, characterization must addrega the change and a new waste summary prepared for TS. Once designated, the waste may be prepared for shipment to storage or disposal.

The following waste Certification summarieg have been prepared and submitted to TS:
(1) Tank Farms Contaminated soil (F-listed)
WSRd $* 720-00$
(2) Tank Contacted Debris (F-ligted)
HSRd $\% 601-01$
or
*81-00
(3) Mercury Contaminated Waste
HSRd $\% 601-01$
or
*810-00
(4) Migcellaneoug Lab Packв
WSRd $\%$ 400-00 or 401-00 or 402-00 or 420-00 or 403-00 or 421-00 or 406-00


BVF-8D-WA-PLN-119, REV. 1

(5) Oily Solid waste and Absorbed Chemical Products

WSRd $\$ 522-00$

or

*920-00

(6) Used Respirator Mask Filter

Cartridges - MSA GMD-H

wSRd $\$ 523-00$

(7) Long-Length Contaminated Equipment (F-listed)

WSRd $\$ 601-01$ a

(8) Radioactive Lead

WSRd $\$ 800-00$

(9) Lead-Acid Battery Spill Waste

WSRd $* 503-00 A$

(10) Nickel-Cadmium (Wet Cell) Battery

wSRd $\$ 830-01$

Acid Contaminated Waste

WSRd $\$ 605-00$

Alkaline Contaminated Waste

WSRd $\$ 606-00$

or

*626-00

\subsection{Non-Regulated Waste}

A CWDR is prepared and submitted to TS, accompanied by chemical characterization information and data. Waste designation is made and a Disposal Analysis record is issued to the generator. The waste may then be shipped for disposal or recycle.

\subsection{Hazardous Chemical Characterization Program goal.}

Hazardous chemical characterization of tank farms containerized solid waste supports Generator Services/Operating Facilities programs. This document will be revised based upon future data and information. The following goals are identified:

(1) Update process knowledge, as needed, to include current tank characterization data as it becomes available.

(2) Continue to sample and analyze containerized solid waste to better define specific waste streams from specific farms in relationship to specific tanks.

(3) Define, trend, and track data collected in support of the waste Certification summary program. 
HNF-SD-WM-PLN-119, REV * 1

REFERENCES

1. WHC-SD-WM-PLN-115, Rev.0, "Waste Shipment Engineering Radionuclide Characterization Program Plan", D.C. Hetzer, January, 1996.

2. Single-Shell Tanks and Double-Shell Tanks Part A, Part B permits.

3. Washington Administrative Code, Dangerous Waste Regulations, 173303.

4. WHC Internal Memo 81100-92-026, "Addition of Listed Waste Codes F001 and F002 to Affected Part A Dangerous Waste Permit Applications", March 23, 1992.

5. WHC Internal Memo 85100-92-DMB-007, "Management Strategy for B Plant Aqueous Low-Level Waste", January 17, 1992.

6. WHC-EP-0342, "242-A Evaporator Process Condensate Stream-Specific Report", Addendum 15, August 31, 1990, pgs. 5-18 to 5-20.

7. WHC Letter with Enclosure $\$ 9159302 \mathrm{D}$, "T Plant Treatment By Generator Request", January 10, 1992.

8. WHC Internal Memo 88400-93-006, "Addition of Listed Waste Code F004 to Affected Dangerous Waste Part A Permit Applications", February 18, 1993.

9. WHC DSI Attachment 88400-93-006, R.D. Pierce to R.J. Julian, "Listed waste Codes for $T$ Plant Tank Waste", February 08, 1993.

10. WHC Internal Memo from Tank Farms ECO, J.R. Kasper, Manager, "Tank Farms Waste Designation by Process Knowledge Document", with attachment 1: Tank Farms Waste Characterization by Process Knowledge; attachment 2: References for available laboratory analysis on tank waste. (JRK:ATH File L/B).

11. Core Composite Sample Data (C-104), November 11, 1986.

12. Internal Letter 65453-85-115, B.M. Maugs to R.A. Kaldor, "Chemical Analysis of 105-AW Sample", June 10, 1985.

13. Internal Letter 65453-85-041, D.R. Bratzel to A.P. Appel, "Characterization of Complexant Concentrate supernatant", February 28,1985 .

14. DSI, R.L. Weiss to V.C. Boyles, "BX Farm Liquid Analysig", March 16,1990 . 
BNF-SD-WM-PLN-119, REV . 1

15. PNL Letter, A.P. Toste to W.G. Richmond, "Selected Physicochemical Properties of Double-Shell Slurry-2 (DSS-2) Waste", September 25, 1987.

16. WHC-SD-WM-DTR-026, Herting, D.L., et al, "Laboratory Characterization of Samples taken in December 1991 (Window E) from Hanford Waste Tanks 241-SY-101, August 20, 1992.

17. WHC-EP-0063-4, Hanford Site Solid Waste Acceptance Criteria.

18. EPA 1986, "Test Methods for Evaluating Solid waste, Physical/Chemical Methods", SW-846, 3rd edition, with promulgated Final Update I package dated July, 1992.

19. $40 \mathrm{CFR}$, Part 261 - Identification and Listing of Hazardous Waste, Subpart C - Characteriatics of Hazardous Waste, Subpart D - Lista of Hazardous Wastes, July 01, 1992.

20. WHC-EP-0846, "Waste Specification System", K.L. Kirkpatrick and B.L. Oswald, January, 1995.

21. WHC-SD-WM-PLN-088, "Hanford Sampling Quality Management Plan (ESQMP) " , 1995. 
HNF-SD-WM-PLN-119, REV. 1

ATTACHMENT A

Table 1-1. Hazardous Constituent Worksheet

\begin{tabular}{|c|c|c|c|c|}
\hline Col. 1 & Col. 2 & Col. 3 & Col. 4 & Col. \\
\hline Constituent & $\begin{array}{c}\mathrm{Ca}-137 \\
\text { Concentration } \\
(\mathrm{Ci} / \mathrm{g} \text { matrix })\end{array}$ & $\begin{array}{c}\text { Constituent } \\
\text { Ratio } \\
\text { (g metal/Ci) }\end{array}$ & Conversion & $\begin{array}{c}\text { Constituent } \\
\text { Concentration } \\
\text { (Wt. \&) }\end{array}$ \\
\hline Ag (D011) & & 2.79 E-05 (11) & $\times 1008$ & 8 \\
\hline $\mathrm{As} \quad$ (D004) & & 2.70 E-01 (12) & $\times 1008$ & 8 \\
\hline $\mathrm{Ba}$ (D005) & & $7.36 \mathrm{E}+01 \quad$ (13) & $\times 1008$ & 8 \\
\hline Cd (D006) & & $3.86 \mathrm{E}+01$ & x 1008 & 8 \\
\hline $\mathrm{Cr}$ (D007) & & $7.20 \quad \mathrm{E}+02$ & $\times 100 \%$ & 8 \\
\hline $\mathrm{Hg}$ (D009) & & $4.17 \mathrm{E}+00$ & $\times 1008$ & 8 \\
\hline $\mathrm{Pb} \quad(\mathrm{D} 008)$ & & $1.19 \mathrm{E}+02$ & $\times 1008$ & s \\
\hline Se (D010) & & $3.65 \mathrm{E}-01$ (16) & $\times 1008$ & 8 \\
\hline
\end{tabular}

Table 1-2. Toxicity Characteristics List

WâC $173-303-090(8)(c)$

\begin{tabular}{||l||c|c|}
\hline Contaminant/Code & $\begin{array}{c}\text { Maximum Conc. } \\
(\mathrm{mg} / \mathrm{l})\end{array}$ & Contaminant Concentration (Wt.8) \\
\hline Argenic (D004) & 5.0 & 0.01 \\
\hline Barium (D005) & 100.0 & 0.2 \\
\hline Cadmium (D006) & 1.0 & 0.002 \\
\hline Chromium (D007) & 5.0 & 0.01 \\
\hline Lead (D008) & 5.0 & 0.01 \\
\hline Mercury (D009) & 0.2 & 0.0004 \\
\hline Selenium (D010) & 1.0 & 0.002 \\
\hline silver (D011) & 5.0 & 0.012 \\
\hline
\end{tabular}

(Toxicity Characteristic Leaching Procedure/TCLP: 20:1 dilution) 
HNF-SD-WA-PLN-119, REV . 1

ATTACHMENT B

TANR FARMS CONTAINERIZED SOLID WASTE SAMPLING AND ANALYSIS PLAN 
HWP-SD-WM-PLN-119, REY . 1

ATIACHENT $B$

TAKK FARUS CONTAINERI ZED SOLID WABTE SANLING AND AYATYSIS PIAN

\section{INTRODUCTION}

Sampling and analysis of containerized solid waste determines or verifies whether or not the waste contains constituente or exhibita a characteristic or criteria that makes it hazardous. For regulatory purposes, hazardous/dangerous solid wastes are defined in terms of characteristics and criteria.

The Resource Conservation Recovery Act (RCRA) authorized the Environmental Protection Agency (EPA) to establish characteristics that make a waste hazardous (40 CFR, Part 261). Washington state has established Dangerous waste characteristics and criteria in WAC 173-303090 and -100 for solid wate. Containers are sampled and analyzed for one or more of the following characteristics depending upon the nature of and what is known about the waste:

(1) Characteristic of Ignitability - D001

(2) Characteristic of Corrosivity - D002

(3) Characteristic of Reactivity - D003

(4) Toxicity characteristic - D004 thru D043

This characteristic includes determinations for toxic, heavy metals, volatile organics (VOAs), and semivolatile organice (SVOAs).

Listed constituents are sampled to, 1) verify listing assumptions, and to, 2) determine if the waste meets Land Disposal Reatriction (IDR) concentrations.

Waste may also be analyzed for other hazardous compounds, formulations, and classes of substances, such as Polychlorinated biphenyle (PCBs).

Washington state criteria consist of:

(1) Toxic dangerous waste,

(2) Persistent dangerous waste. 
These criteria are determined by book designation (NIOSH RTECs) or biological testing for the toxic criteria and identifiying halogenated or polycyclic aromatic hydrocarbon constituents in the waste for the persietent criteria.

\section{OBJECTIVES}

The objective of this sampling and analysis plan is to state the steps and requirements needed in acquiring representative solid waste samples for chemical analysia.

Solid waste samples are collected from containers and analyzed to resolve the following waste characterization isgues:

(1) to determine if hazardous constituents or characteristics are present.

(2) to determine compliance with existing regulations by identifying contaminanta which exceed any criteria or otandards. to obtain data to classify, treat, recover, recycle, or determine compatibility characteristics of the waste componente.

III . RESPONSPONSIBILITIES

Generator Services/Operations (Gs/O)

- Provide support and oversight of outside sampling organizations during sampling activities according to Tank Farm Plant Cparating Procedure, To-100-053.

Generator Services/Operating Facilities (GS/OF)

- Defines, confirms, and verifies hazardous chemical characterization of containerized solid waste.

- Identifies solid waste containers in need of aampling and analyaig.

- Interface between GS/O and outside sampling organizations.

- Requeata waste sampling and analyses from SML, SAs, 222-s laboratory, or WSCF.

- Performs designation of waste based upon characterization data.

Sampling and Mobile Laboratories (SML)

- Collectg specified samples.

- Ships samples to on-site and off-site laboratories.

- Maintains field logbook, prepares chain-of-cugtody recorde. 
EWF-8D-WM-PLN-119, REV . 1

Special Analytical Support (SAS)

- Provides trained scientiets/technicians for field sampling and laboratory analyeis of specified samples.

- Transports samples to laboratoriea.

- Documents sampling activities in a controlled logbook, prepares chain-of-custody records.

- Generates data report detailing analytical results, methodg used, quality control samples.

\section{REQUIREMENTS}

\section{SAFETY}

ALARA principles must be taken into account when any sampling job is undertaken and in determining the waste containers to be sampled. Prior to beginning a sampling job, GS/OF and GS/O will addreeg any and all safety concerns (i.e., exposure to radiation, organic vapors, asbestos, mercury, or biohazards). When appropriate, Health Physics (HP) and Industrial Health and Safety personnel will be present at the pre-job meeting and during the sampling job to address and monitor any potential safety hazard.

QUALITY ASSURANCE/QUALITY CONTROL

Sampling is the physical collection of a representative portion of the waste. A representative sample must be collected and handled in such a way as to preserve its original physical form and chemical composition, as well as to prevent contamination or changes in the concentration of the constituents to be analyzed. Sample integrity must be ensured and quality assurance standards maintained for a sample to be typical of the waste. QA/QC requirements are guided by the document, "Hanford Sampling quality Management Plan (HSQMP)", WHC-SD-WM-PLN-088.

The collection, handling, and preparation of samples shall comply with the protocol of "Test Methods for Evaluating Solid Waste, Physical/Chemical Methods, SW-846". Other documented, verifiable techniques, guch as ASTM methods, may be used when appropriate for the waste matrix. Composite samples of the waste matrices will be collected from the container. Field screening techniques may be used when appropriate, but should be verified with laboratory confirmation, if not an approved method.

Sampling personnel must adhere to and use appropriate sampling techniques, sampling equipment, precleaned bottles, chain-of-custody procedures, sample holding times, preservatives, and complete a controlled logbook entry to ensure proper quality control of the sample. 
HNF-SD-WM-PLW-119, REV . 1

\section{CHAIN-OF-CUSTODY/FIELP LOOBOOK}

A chain-of-custody form will be filled out at the time of sampling and shall accompany each waste characterization sample. A sample may consist of several containers. The chain-of-custody will account for the whereabouts and handling of a sample and data from the point of collection to final determination.

All activities associated with the sampling event will be documented in a controlled field logbook. The sampling team shall retain ownership of the field logbook. Photocopies of the field logbook entries shall be forwarded to the GS/OF representative upon completion of the sampling event.

\section{QALOC SAYPLES}

\section{Trip Blanks}

Trip blanks shall be collected every twentieth sample event. The trip blank shall be collected by filling a sample bottle with pre-certified silica sand, in order to apply for a solid matrix. Trip blanks should be treated and labeled in the same manner as the samples.

\section{Duplicate Samples}

One duplicate sample shall be collected for every 20 actual samples. duplicate sample will be collected at the same time and from the same sample composite. The duplicate shall be analyzed for the same constituents as the actual sample that it represents. The laboratory analyzing the samples shall not be able to ascertain the exiatence of a duplicate sample thru any accompanying documentation.

\section{Laboratory split Samples}

At a minimum, 108 of the samples taken shall be collected as split samples to be sent to different laboratories.

\section{v. SAMPLING AND ANALYTICAI ORGANIZATIONS}

Presently, two on-gite organizations are available and capable of sampling tank farm containerized solid waste.

\section{BPECIAL ANALYTICAL SUPPORT (SAS)}

SAS performs the following:

Samples solid waste containers, transports sample to 222-s or the WSCF laboratory for activity screening, if required, and then performs sample analysis at their on-site laboratory facilities. 
(2) Samples solid waste containers, traneports sample to 222-s

laboratory for activity screening, if required, and then

transports sample for analyais to an off-site laboratory.

Performs field asgessment analytical tests (HAzCAT) on a waste

with follow-up verification on-site laboratory analysis.

The SAS group follows sampling procedures outlined in WHC-CK-7-7,

"Environmental Investigations and Site Characterization Manual". The SAS group uses analytical methods outlined in WHC-IP-1128, "special Analytical Services Procedures". GS/OF only requests SAS to perform sampling and analytical methods adhering to SW-846 protocol for waste designations.

SAMPLING AND NOBILE LABORATORIES (SMT)/HANFORD SAMPLE DATA AND LABORATORY ADMINISTRATION (BDLA)/ANALYTICAL BERVICES (AS)

SML samples containers and transports the samples for analysis to onsite laboratories or an off-site laboratory. SMI uses sampling procedures outlined in WHC-CM-7-7, "Environmental Investigations and Site Characterization Manual" and WHC-IP-1127, "Sample Mobile Laboratories Procedures Manual". GS/OF requests sML to perform sampling methods adhering to SW-846 protocol.

As coordinates the requested analyses of the samples with the off-site laboratories. AS verifies that the requested analytical methods adhere to SW-846 protocol.

vI. SAMPLING AND ANALYSIS COURSE OF ACTION

The steps GS/OF follows for acquiring characterization data thru sampling and analysis of solid waste are:

(1) Review the Package Identification Number (PIN) file associated with the waste container. The review should be done as soon as possible after the container arrives at the Gs facility.

(2) Determine the number and identity of waste containers to be sampled.

(3) Determine the analytes of interest to be requested for ampling. Determine the analytical method needed to be performed on the sample.

(4) Choose the on-site sampling organization for the job.

(5) Make the job request to the eampling and laboratory organization by using the "Sampling and Analysia Request Form - GS/OF". (See Attachment c). 
ENT-SD-WL-PL.N-119, REV. 1

(6) GS/OF schedules date and time of sample job. GS/O mugt approve scheduled sample date. GS/O supports and oversees the sampling team personnel during the job. GS/O arranges any required HP or Industrial safety and Health support for the job.

On the day of sampling the following course of action occurs:

(7) A pre-job occurg with the sampling team, GS/O, Gs/OF, and if required HPG, and ISH personnel. Any and all gafety concerns should be discussed at the pre-job. Additional information concerning the waste is provided to the sampling team, if requested.

(8) Sample team takes the samples. The sample team completes the field logbook entries, chain-of-custody form, labels and seals the sample bottles, and packages the samples for transport to the laboratory. The sample team transports the eamples to the laboratory.

Upon completion of the sampling job, the following course of action occurs:

(9) Sample activity data for mixed or low-level waste is received from the lab by GS/OF.

(10) Chemical analytical data is received from the laboratory. The data is received from the laboratory according to set priority. (One to six weeks)

(11) Review and summary of data is made by GS/OF personnel.

(12) Place data summary, data package, chain-of custody form, sample request, in PIN file for documentation.

(13) Sample waste may be returned to GS/OF or prior arrangements may be made with analytical lab to dispose of sample waste. 


\section{ATTACHMENT C}

ID No./Project Title:

Org Code/Charge Code:

Work Order No.:

Pre-Job Location/Time:

Job Description/Job No.:
SAMPLING AND ANALYSIS REQUEST FORM - GS/OF

Date:

Contact:

Phone \#:

FAX \#:

MSIN:

Sample Matrix:

Sampling Location:

Radioactive:

No. of Samples:

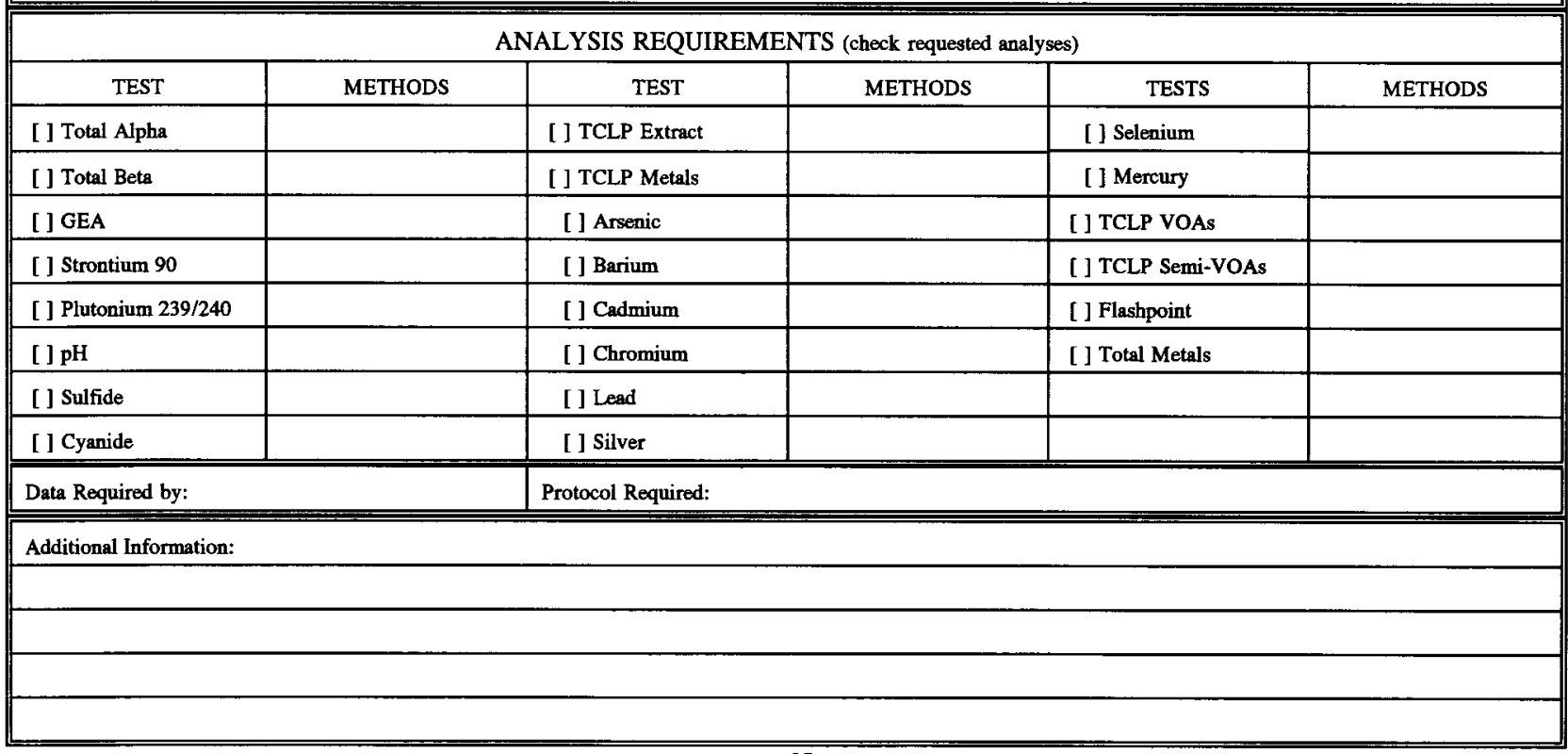




\begin{tabular}{|c|c|c|c|c|c|}
\hline \multicolumn{6}{|c|}{ DISTRIBUTION SHEET } \\
\hline \multirow{2}{*}{$\begin{array}{l}\text { To } \\
\text { Distribution }\end{array}$} & \multirow{2}{*}{\multicolumn{3}{|c|}{$\begin{array}{l}\text { From } \\
\text { Generator services/Operating } \\
\text { Facilities }\end{array}$}} & \multicolumn{2}{|l|}{ Page 1 of 1} \\
\hline & & & & \multicolumn{2}{|c|}{ Date $3 / 31 / 97$} \\
\hline \multicolumn{4}{|c|}{ Project Title/Work Order } & \multicolumn{2}{|l|}{ EDT No. } \\
\hline $\begin{array}{l}\text { Tank Farms solid Waste } \\
\text { Analysig Plan Attachment }\end{array}$ & \multicolumn{3}{|c|}{ Guide With Sampling and } & \multicolumn{2}{|c|}{ ECN No. 635186} \\
\hline Name & MSIN & $\begin{array}{l}\text { Text } \\
\text { With All } \\
\text { Attach. }\end{array}$ & Text Only & $\begin{array}{l}\text { Attach./ } \\
\text { Appendix } \\
\text { Only }\end{array}$ & $\begin{array}{c}\text { EDT/ECN } \\
\text { Only }\end{array}$ \\
\hline P. A. Gagnon & $s 6-31$ & $\mathrm{x}$ & & & \\
\hline K. A. George & $56-30$ & $\mathbf{x}$ & & & \\
\hline D. C. Hetzer & $s 6-31$ & $\mathrm{x}$ & & & \\
\hline M. E. Lakes & $s 6-31$ & $\mathbf{x}$ & & & \\
\hline J. T. Quigley & s6-30 & $\mathrm{x}$ & & & \\
\hline B. E. Salazar & $56-30$ & $\mathbf{x}$ & & & \\
\hline F. C. Schmidt & s6-30 & $\mathrm{x}$ & & & \\
\hline Y. M. Shehadeh & $s 6-30$ & $\mathrm{x}$ & & & \\
\hline
\end{tabular}

